\title{
The use and reporting of airline passenger data for infectious disease modelling: a systematic review
}

Margaux Marie Isabelle Meslé ${ }^{1,2}$, Ian Melvyn Hall ${ }^{1,3,4,5}$, Robert Matthew Christley ${ }^{1,2}$, Steve Leach ${ }^{1,4,5,6}$, Jonathan Michael Read ${ }^{1,2,7}$

1. National Institute for Health Research, Health Protection Research Unit in Emerging and Zoonotic Infections at University of Liverpool, Liverpool, United Kingdom

2. Institute of Infection and Global Health, University of Liverpool, Liverpool, United Kingdom

3. School of Mathematics, University of Manchester, Manchester, United Kingdom

4. Emergency Response Department, Public Health England, Salisbury, United Kingdom

5. National Institute for Health Research, Health Protection Research Unit in Emergency Preparedness and Response at Kings College London, London, United Kingdom

6. National Institute for Health Research, Health Protection Research Unit in Modelling Methodology at Imperial College London, London, United Kingdom

7. Centre for Health Informatics Computation and Statistics, Lancaster Medical School, Lancaster University, Lancaster, United Kingdom

Correspondence: Jonathan Read (jonathan.read@lancs.ac.uk)

Background: A variety of airline passenger data sources are used for modelling the international spread of infectious diseases. Questions exist regarding the suitability and validity of these sources. Aim: We conducted a systematic review to identify the sources of airline passenger data used for these purposes and to assess validation of the data and reproducibility of the methodology. Methods: Articles matching our search criteria and describing a model of the international spread of human infectious disease, parameterised with airline passenger data, were identified. Information regarding type and source of airline passenger data used was collated and the studies' reproducibility assessed. Results: We identified 136 articles. The majority $(n=96)$ sourced data primarily used by the airline industry. Governmental data sources were used in 30 studies and data published by individual airports in four studies. Validation of passenger data was conducted in only seven studies. No study was found to be fully reproducible, although eight were partially reproducible. Limitations: By limiting the articles to international spread, articles focussed on within-country transmission even if they used relevant data sources were excluded. Authors were not contacted to clarify their methods. Searches were limited to articles in PubMed, Web of Science and Scopus. Conclusion: We recommend greater efforts to assess validity and biases of airline passenger data used for modelling studies, particularly when model outputs are to inform national and international public health policies. We also recommend improving reporting standards and more detailed studies on biases in commercial and open-access data to assess their reproducibility.

\section{Introduction}

International movement of individuals through commercial airline travel has been implicated in the transnational dissemination of many infectious diseases and is thought to be the principle mode of human pathogen transfer between continents. Examples include the global dissemination of the outbreak of severe acute respiratory syndrome in 2003 which quickly spread from Hong Kong to North America [1]. The 2009 influenza pandemic [2], which emerged in Mexico and affected more than 208 countries, followed a similar international dissemination [3]. There is, year-on-year, an increasing number of airline travellers, with a total of 1,186 million international tourist arrivals globally in 2015, a 4.6\% increase from 2014 and 510 million arrivals more than in 2000 [4]. In addition, tourism visits to emerging economies are now comparable to those of high-income countries, with countries such as Mexico and Thailand entering the top 15 of the most visited destinations. The global trend is expected to keep rising and reach 1.8 billion arrivals in 2030 [4]. Lower fares and greater availability make geographically distant destinations easier to reach for a greater number of people [5].

With the volume of airline passengers increasing each year [6], it is important to understand the dynamics of the airline network and its role in disease spread and control [7]. We need to be able to accurately predict international transmission through passenger flow. Mathematical models are useful tools that can estimate the risk of infectious disease importation and exportation by international airline passengers [8], especially in the early stages of an outbreak when 
TABLE 1A

Systematic review on airline passenger data in infectious disease modelling, (A) fields recorded and (B) criteria used to determine reproducibility of articles and sources

\section{A. Data description}

Article information

\begin{tabular}{|l|c|c|}
\hline Authors & At least the first three authors, as on article & Text \\
\hline Year of publication & Date \\
\hline Title & Text \\
\hline Publication name & Text \\
\hline Data & \\
\hline
\end{tabular}

Data source

Commercial data

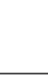

Tourism surveys

National passenger surveys

Airport published information

Commercial databases collecting information about flight routings, aircraft size, number of bookings or passengers, e.g. IATA, OAG, Diio Any surveys done in the context of tourism, e.g. UNWTO

Government immigration data Surveys conducted at airports, e.g. passenger survey Data collected and published by airports, may be groups of airports

Other ata collected by governments on migration numbers, inbound passengers

Unreported or unclear E.g. information published by airlines

Yes/no

Data type

Seat capacity

Itinerary

Number of flights

Number of passengers

Tickets sold

Origin-destination information

Direct flight information only

Unreported or unclear

Data time period

Date range of data is reported

Date range

Reporting quality (scoring criteria see Table part B)

\begin{tabular}{|c|c|c|}
\hline Fully reproducible & $\begin{array}{l}\text { All handling and manipulation of the data is described to a detail adequate to } \\
\text { enable reproducibility } \\
\text { (reproducibility score }=4)\end{array}$ & Yes/no \\
\hline Partially reproducible & $\begin{array}{l}\text { Important information on handling of the data is missing, or methodology is } \\
\text { vague } \\
\text { (reproducibility score }=3 \text { ) }\end{array}$ & Yes/no \\
\hline Not reproducible & $\begin{array}{l}\text { Information on methods and/or data source is missing and methodology unclear } \\
\qquad \text { (reproducibility score } \leq 2)\end{array}$ & Yes/no \\
\hline \multicolumn{3}{|l|}{ Data validation } \\
\hline Data validation attempted & $\begin{array}{l}\text { A comparison was made with an independent and appropriate source of } \\
\text { information }\end{array}$ & Yes/no \\
\hline \multicolumn{3}{|l|}{ Data usage } \\
\hline Transmission model & Airline passenger information is used to parameterise a model of transmission & Yes/no \\
\hline Network analysis & Airline passenger information is described using social network methodology & Yes/no \\
\hline Descriptive or illustrative & $\begin{array}{l}\text { Airline passenger information is used to illustrate a transmission risk, but no } \\
\text { formal analysis or modelling is performed }\end{array}$ & Yes/no \\
\hline Other & None of the above (specify or describe what was done) & Yes/no \\
\hline Unclear or unreported & Insufficient information to determine data usage & Yes/no \\
\hline
\end{tabular}

Diio: data in, intelligence out; IATA: International Air Transport Association; MERS: Middle East respiratory syndrome; OAG: company providing air travel data; UNWTO: World Tourism Organization. 
Systematic review on airline passenger data in infectious disease modelling, (A) fields recorded and (B) criteria used to determine reproducibility of articles and sources

\begin{tabular}{|c|c|c|}
\hline \multicolumn{3}{|l|}{ A. Data description } \\
\hline \multicolumn{3}{|l|}{ Pathogen modelled } \\
\hline Non-specific & Generic model & Yes/no \\
\hline \multicolumn{2}{|l|}{ MERS coronavirus } & Yes/no \\
\hline \multicolumn{2}{|l|}{ Seasonal influenza } & Yes/no \\
\hline \multicolumn{2}{|l|}{ Pandemic influenza } & Yes/no \\
\hline \multicolumn{2}{|l|}{ Other (specify) } & Text \\
\hline \multicolumn{3}{|l|}{ B. Reproducibility ${ }^{a}$} \\
\hline \multicolumn{2}{|c|}{ Data accessibility (mutually exclusive categories) } & Score contribution ${ }^{b}$ \\
\hline Open source & $\begin{array}{c}\text { Publicly available, no restrictions on use, no access fees, and source (where } \\
\text { online) still accessible as at January } 2017\end{array}$ & Yes $=+1 ;$ No $=0$ \\
\hline Closed source & $\begin{array}{c}\text { Publicly available but restricted access, access may be granted following } \\
\text { registration and/or fee, e.g. proprietary data }\end{array}$ & Yes $=0 ;$ No $=0$ \\
\hline Not publicly available & $\begin{array}{c}\text { Private data, access at discretion of custodian, e.g. airport or airline company } \\
\text { information }\end{array}$ & Yes $=0 ; \mathrm{No}=0$ \\
\hline \multicolumn{2}{|c|}{ Reporting clarity of data source } & $(\text { All Yes }=+1)^{c}$ \\
\hline Source identified & The source of the original data is clearly stated & Yes/no \\
\hline Data set named & The specific name of the data set or database in the source is reported & Yes/no \\
\hline Access date specified & The date(s) on which data were accessed is reported & Yes/no \\
\hline Data type reported & $\begin{array}{c}\text { The type or unit represented by the data is reported, e.g. number of flights/seats/ } \\
\text { passengers }\end{array}$ & Yes/no \\
\hline \multicolumn{3}{|c|}{ Reporting clarity of data usage } \\
\hline Data handling reported & $\begin{array}{l}\text { Data manipulation before analysis, including data cleaning and/or aggregation, is } \\
\text { reported }\end{array}$ & Yes $=+1 ;$ No $=0$ \\
\hline \multicolumn{3}{|l|}{ Date range of data used } \\
\hline Data time range reported & The time period covered by the data is reported & $\mathrm{Yes}=+1 ; \mathrm{No}=0$ \\
\hline Total reproducibility score & $\begin{array}{l}\text { Maximum score }=4 . \\
\text { If multiple sources were used in an article, the average score was cal }\end{array}$ & ulated. \\
\hline
\end{tabular}

Diio: data in, intelligence out; IATA: International Air Transport Association; MERS: Middle East respiratory syndrome; OAG: company providing air travel data; UNWTO: World Tourism Organization.

a If studies used a third party's travel model and if they did not describe the model fully but provide a link or citation, we assessed the cited external documentation for reproducibility.

${ }^{\text {b }}$ Only material using open source data contributes +1 point to the reproducibility score.

'The material must receive a 'yes' for all subvariables for this variable to contribute +1 point to the reproducibility score.

accurate reporting may be difficult [9]. Models such as the one developed by Lopez et al. use the force of infection in the visited country to determine the risk to international visitors, assuming an arbitrary number of airline passengers [8]. However, this risk can also extend to new areas when returning passengers carry pathogens back to their country of residence, as was the case in Italy in 2007, when an autochthonous chikungunya outbreak occurred following importation [10]. Mathematical models of pathogen importation/ exportation risks usually entail a function of the infection level in the visited country and the airline passenger volume between the two involved geographical locations, as described by Quam and Wilder-Smith [11]. Access to accurate and appropriate data sets describing passenger flow between locations is crucial when developing transmission models of global spread [12]; such models can explore the potential role the airline network may play in the spread of disease, but also predict future spread, particularly when new threats emerge. However, a variety of data sources have been used leading to inconsistency and incomparability between modelling studies [7]. The sources themselves are generally not designed for epidemic modelling purposes. They include data for use within the aviation industry, which may be expensive to access and impose user restrictions, including prohibition to share with a third party $[7,12]$. Open-access data sources do exist but may be geographically restricted, provide information in forms not easily convertible into passenger numbers or are limited in temporal resolution [7].

To gain an overview of the range of airline passenger data sources used by modelling studies, a systematic literature review was designed and conducted. The principal aim of the review was to determine the data 


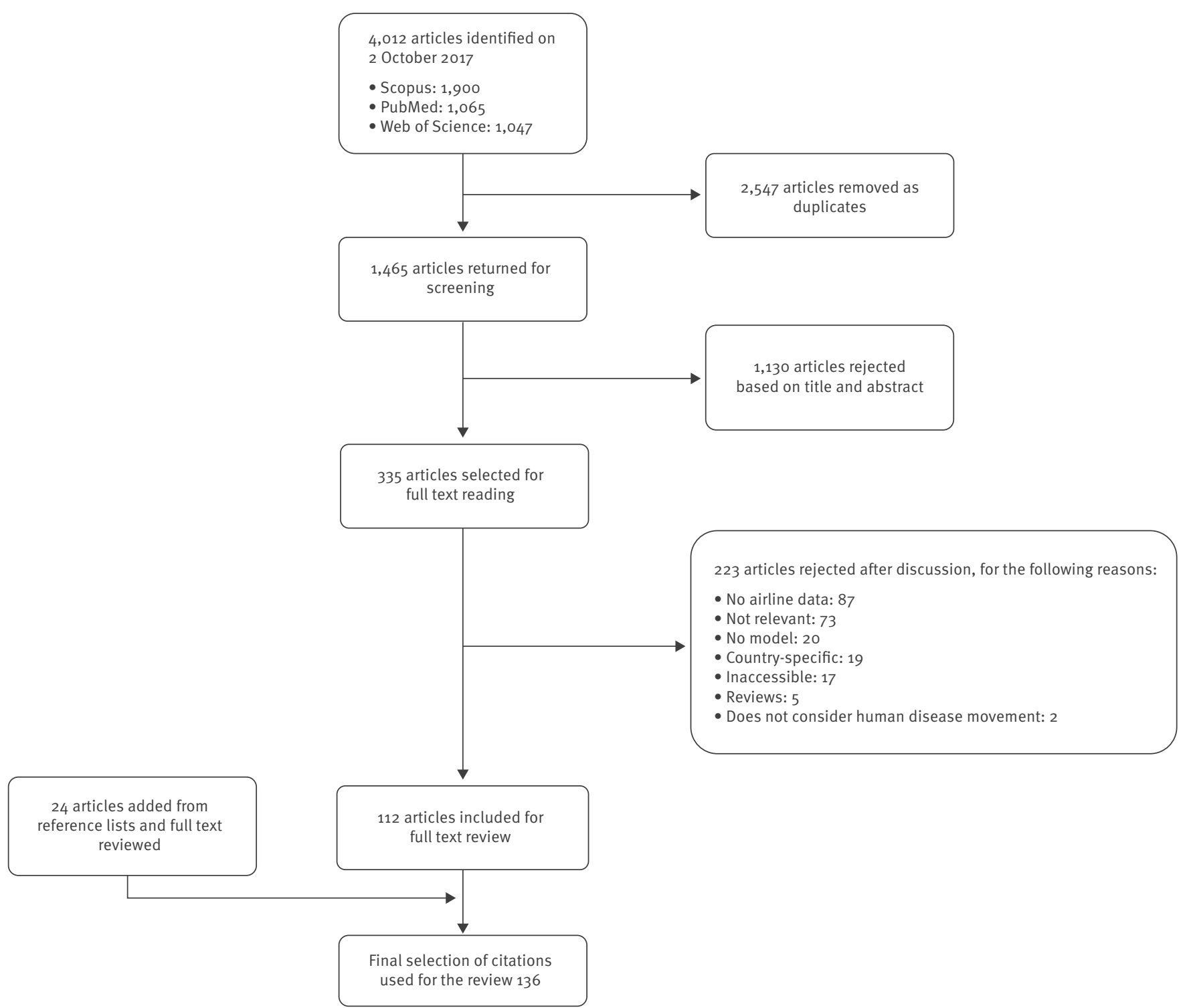

types (e.g. passenger numbers and seat capacity) and sources used for the purposes of modelling international infectious disease importation. A secondary aim of the review was to assess the reproducibility of those studies regarding sourcing and use of airline passenger data.

\section{Methods}

\section{Search strategy}

We conducted a search of the literature on 2 October 2017 using PubMed, Web of Science and Scopus with no restriction on the earliest date of the articles returned. A combination of three sets of search terms was used in this review (\#1 AND \#2 AND \#3). The first set (\#1) was: 'air' OR 'airline' OR ‘aviation' OR 'flight' OR 'airport' OR 'passenger' OR 'transport*' OR 'travel*' AND NOT 'pollution'. The second set (\#2) was: ‘epidemic’ OR 'pandemic'. The final set (\#3) was: 'global' OR 'international'. The term 'pollution' was classed as an exclusionary term as initial scoping suggested that a large proportion of results included pollution studies, which were deemed irrelevant to this review.

We included articles if they matched the following inclusion criteria: (i) they were primary and peerreviewed research; (ii) they modelled the international spread of human infectious diseases between at least two countries and (iii) the model was parameterised with airline passenger data. We included modelling studies which considered either dynamic models of the transmission process or non-dynamic modelling of the movement of infected individuals. We also permitted the inclusion of any additional articles if they were identified as the source of passenger data used in already selected articles and met the three inclusion 
TABLE 2A

Systematic review on airline passenger data in infectious disease modelling, list of selected articles with name of data source, information on data validation and reproducibility score $(\mathrm{n}=136)$

\begin{tabular}{|c|c|c|c|}
\hline Reference & Sources used & Validation & Reproducibility score ${ }^{a}$ \\
\hline Ajelli et al, 2009 [22] & IATA & No & 0 \\
\hline Apenteng et al, 2014 [78] & Malaysian Department of Statistics & No & 2 \\
\hline Apolloni et al, 2013 [79] & $\begin{array}{l}\text { Airports: Amsterdam, Frankfurt, Gatwick, Hamburg, Hannover, } \\
\text { Heathrow, Helsinki, Luton, Munich, Stansted, Teheran, Venice }\end{array}$ & No & $0.33(0,0,1,0,1,0)$ \\
\hline Arino et al, 2015 [8o] & IATA & No & 1 \\
\hline Bajardi et al, 2011 [42] & IATA & No & 0 \\
\hline Balcan et al, 2009 [21] & IATA & No & 0 \\
\hline Balcan et al, 2010 [23] & IATA and OAG & No & $\mathrm{o}(\mathrm{o}, \mathrm{o})$ \\
\hline Balcan et al, 2009 [24] & IATA and OAG & No & $\mathrm{o}(\mathrm{o}, \mathrm{o})$ \\
\hline Bedford et al, 2015 [50] & Civil Aviation Authority & No & 3 \\
\hline Bobashev et al, 2008 [35] & OAG & No & 2 \\
\hline Bogoch et al, 2016 [81] & IATA & No & 2 \\
\hline Bogoch et al, 2016 [82] & IATA & No & 2 \\
\hline Bogoch et al, 2015 [25] & IATA & No & 2 \\
\hline Bowen et al, 2006 [83] & OAG (OAG MAX) & No & 1 \\
\hline Brannen et al, 2016 [84] & $\begin{array}{c}\text { US Department of Transportation (Air Carrier Activity Information } \\
\text { System) }\end{array}$ & No & 2 \\
\hline Brennan et al, 2013 [51] & Twitter & No & 3 \\
\hline Brigantic et al, 2009 [62] & US Department of Transport & No & 1 \\
\hline Brockmann et al, 2013 [36] & OAG & No & 0 \\
\hline Brockmann et al, 2007 [85] & IATA and OAG & No & $0(0,0)$ \\
\hline Brown et al, 2012 [86] & Civil Aviation Authorities & No & 2 \\
\hline Caley et al, $2007[87]$ & Unknown & No & 0 \\
\hline Carias et al, 2016 [37] & OAG & No & 2 \\
\hline Cauchemez et al, 2014 [88] & IATA & No & 1 \\
\hline Chang et al, $2010[52]$ & Feeyo & No & 3 \\
\hline Cheng et al, 2017 [89] & ICAO & No & 1 \\
\hline Chong et al, 2014 [9o] & Unknown & No & 2 \\
\hline Chong et al, 2012 [91] & Hong Kong Tourism Board & No & 1 \\
\hline Clements et al, 2010 [6o] & IATA & No & 0 \\
\hline Colizza et al, 2007 [26] & IATA & No & 0 \\
\hline Colizza et al, 2006 [27] & IATA & No & 1 \\
\hline Colizza et al, 2006 [28] & IATA & No & 1 \\
\hline Colizza et al, 2007 [92] & IATA & No & 0 \\
\hline Colizza et al, 2008 [29] & IATA & No & 0 \\
\hline Colizza et al, 2007 [30] & IATA & No & o \\
\hline Colizza et al, 2008 [31] & IATA & No & 0 \\
\hline Cooper et al, 2006 [93] & IATA & No & 1 \\
\hline Corley et al, 2012 [64] & US Department of Transport; OpenFlights.org; OurAirports.com & No & $1.33(2,1,1)$ \\
\hline Daniel et al, 2013 [20] & {$[15,19]$} & No & $0.5(0.4,0.6)^{b}$ \\
\hline Dembele et al, 2017 [94] & Unknown & No & o \\
\hline Dorigatti et al, 2017 [95] & $\begin{array}{l}\text { UNWTO; } \\
\text { Brazilian Ministry of Tourism }\end{array}$ & No & $2.5(2,3)$ \\
\hline Ekdahl et al, 2005 [13] & Swedish Tourist and Travel Database & Yes & 3 \\
\hline Epstein et al, 2007 [96] & OAG (OAG MAX) & No & 0 \\
\hline Flahault et al, 1994 [14] & IATA & No & 0 \\
\hline Flahault et al, 2006 [97] & $\begin{array}{c}\text { US Department of Transport; OAG; IATA; ICAO; Back Aviation Solutions; } \\
\text { Air Transportation Statistics; Australian International Arrivals; Airbus } \\
\text { Industries; Boeing corporation; unknown }\end{array}$ & No & $\begin{array}{c}0.8(2,1,1,1,1,0,0 \\
0,1,1)\end{array}$ \\
\hline Fraser et al, 2009 [2] & OAG & No & 2 \\
\hline
\end{tabular}

ACI: Airport Council International; Diio: data in, intelligence out; IATA: International Air Transport Association; ICAO: International Civil Aviation Organization; OAG: company providing air travel data; OAG MAX: product produced by OAG; UK: United Kingdom; UNWTO: World Tourism Organization; US: United States.

${ }^{a}$ Average total score shown, with individual source scores shown in brackets where multiple sources used.

${ }^{b}$ Where the cited data source was another article, the average score of that article was used. 


\section{TABLE 2B}

Systematic review on airline passenger data in infectious disease modelling, list of selected articles with name of data source, information on data validation and reproducibility score $(\mathrm{n}=136)$

\begin{tabular}{|c|c|c|c|}
\hline Reference & Sources used & Validation & Reproducibility score ${ }^{a}$ \\
\hline Gardner et al, 2017 [98] & IATA (Passenger Intelligence Services) & No & 2 \\
\hline Gardner et al, 2013 [53] & IATA & No & 3 \\
\hline Gardner et al, 2016 [99] & IATA (Air passenger market analysis) & No & 2 \\
\hline Gardner et al, 2012 [54] & US Department of Transport & No & 3 \\
\hline Gardner et al, 2012 [100] & $\begin{array}{l}\text { US Department of Transport; } \\
\text { Eurostat }\end{array}$ & No & $2.5(3,2)$ \\
\hline Gardner et al, 2015 [101] & IATA & No & 2 \\
\hline Gautreau et al, 2007 [102] & IATA & No & 0 \\
\hline Gautreau et al, 2008 [57] & IATA & Yes & 0 \\
\hline Goedecke et al, 2007 [103] & OAG (OAG MAX) & No & 2 \\
\hline Gomes et al, 2014 [66] & IATA; OAG & No & $\mathrm{o}(0,0)$ \\
\hline Gonçalves et al, 2013 [43] & IATA; OAG & No & $\mathrm{o}(0,0)$ \\
\hline Goubar et al, 2009 [104] & ICAO; National Bureau of Statistics of China & No & $1(1,1)$ \\
\hline Grais et al, 2003 [15] & $\begin{array}{l}\text { US Department of Transport; OAG; IATA; ICAO (Traffic by Flight Stage); } \\
\text { Back Aviation Solutions; Air Transportation Statistics; Australian } \\
\text { International Arrivals; Airbus Industries; Boeing corporation; unknown }\end{array}$ & No & $\begin{array}{l}0.3(2,0,0,0,0,0,0 \\
0,0,1)\end{array}$ \\
\hline Grills et al, 2016 [105] & Diio & No & 1 \\
\hline Hanvoravongchai et al, 2011 [106] & Mexican Secretary of communication and transport & No & 2 \\
\hline Hatz et al, 2009 [107] & $\begin{array}{l}\text { UNWTO; } \\
\text { UK Office for National Statistics }\end{array}$ & No & $2(1,3)$ \\
\hline Hollingsworth et al, 2006 [108] & $\begin{array}{l}\text { Beijing Capital International Airport (Traffic Data); Hong Kong } \\
\text { International Airport (Provisional Civil International Air Traffic } \\
\text { Statistics); IATA }\end{array}$ & No & $0.67(1,1,0)$ \\
\hline Hollingsworth et al, 2007 [109] & $\begin{array}{c}\text { IATA (International Travel Statistics); Hong Kong International Airport; } \\
\text { Beijing Capital Airport }\end{array}$ & No & $0.67(1,1,0)$ \\
\hline Hosseini et al, 2010 [32] & IATA & No & 1 \\
\hline Hsu et al, $2010[110]$ & Amadeus; Landing.com & No & $0.5(0,1)$ \\
\hline Hufnagel et al, 2004 [16] & IATA; OAG & No & $\mathrm{o}(0,0)$ \\
\hline Hwang et al, 2012 [111] & Diio & No & 2 \\
\hline Johansson et al, 2012 [112] & OAG (Traffic Analyser); US Department of Transport & No & $0.5(0,1)$ \\
\hline Johansson et al, 2011 [65] & OAG (Traffic Analyser); US Department of Transport & No & $0.5(0,1)$ \\
\hline Johansson et al, 2014 [113] & Diio & No & 2 \\
\hline Kenah et al, $2011[114]$ & Unknown & No & o \\
\hline Kernéis et al, 2008 [115] & US Department of Transport; OAG; IATA; ICAO; Back Aviation Solutions & No & $0.4(2,0,0,0,0)$ \\
\hline Khan et al, 2009 [116] & IATA & No & 1 \\
\hline Khan et al, 2014 [75] & IATA & No & 2 \\
\hline Khan et al, 2013 [58] & IATA & Yes & 2 \\
\hline Khan et al, $2010[48]$ & Unknown & No & 2 \\
\hline Khan et al, 2012 [61] & IATA & No & 1 \\
\hline Khan et al, $2010[117]$ & $\begin{array}{l}\text { ACl; Saudi Arabia Authority of Civil Aviation; IATA (Worldwide passenger } \\
\text { ticket sales) }\end{array}$ & No & $1(1,2,0)$ \\
\hline Khan et al, 2013 [118] & IATA & No & 2 \\
\hline Knipl et al, 2013 [119] & Statistics Canada; unknown & No & $1(1,1)$ \\
\hline Lawyer, $2016[120]$ & OpenFlights.org & No & 2 \\
\hline Lemey et al, 2014 [38] & OAG & No & 1 \\
\hline Longini, 1988 [17] & [21] & No & $0.6 \mathrm{~b}$ \\
\hline Longini et al, 1986 [18] & $\begin{array}{c}\text { Air Transport Statistics; Australian International Airport traffic } \\
\text { dynamics; ABC World Airways Guide; OAG; ICAO }\end{array}$ & No & $0.4(0,1,0,0,1)$ \\
\hline Lourenço et al, 2014 [121] & Airport: Madeira & No & 1 \\
\hline Malone et al, 2009 [63] & US Department of Transport & No & 1 \\
\hline Marcelino et al, 2009 [39] & OAG & No & 2 \\
\hline Marcelino et al, 2012 [122] & OAG & No & 2 \\
\hline
\end{tabular}

ACI: Airport Council International; Diio: data in, intelligence out; IATA: International Air Transport Association; ICAO: International Civil

Aviation Organization; OAG: company providing air travel data; OAG MAX: product produced by OAG; UK: United Kingdom; UNWTO: World Tourism Organization; US: United States.

${ }^{a}$ Average total score shown, with individual source scores shown in brackets where multiple sources used. 
TABLE 2C

Systematic review on airline passenger data in infectious disease modelling, list of selected articles with name of data source, information on data validation and reproducibility score $(\mathrm{n}=136)$

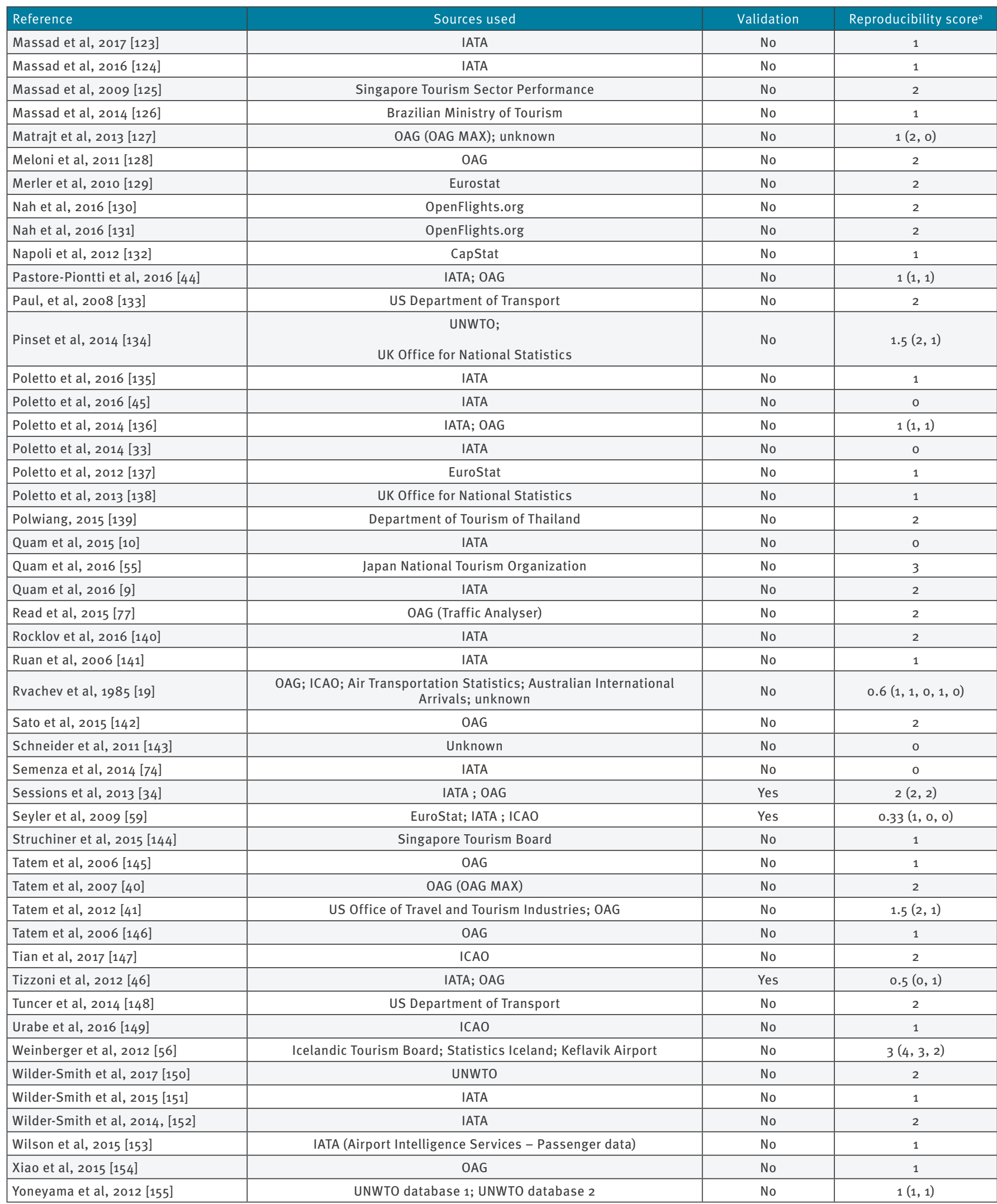

ACI: Airport Council International; Diio: data in, intelligence out; IATA: International Air Transport Association; ICAO: International Civil

Aviation Organization; OAG: company providing air travel data; OAG MAX: product produced by OAG; UK: United Kingdom; UNWTO: World

Tourism Organization; US: United States.

average total score shown, with individual source scores shown in brackets where multiple sources used. 
criteria above. Although no language restriction was applied to the searches, articles in a language other than English were excluded during the abstract review if no translated version of the abstract could be found. Review articles not containing primary research were also excluded, unless they addressed specifically the use of airline passenger data in epidemic modelling. Articles for which an abstract could not be accessed were excluded at this stage.

Following deduplication, the full list of abstracts and titles was reviewed and included or excluded by at least two reviewers independently. Any disagreement regarding inclusion of an article in the review was then discussed between all reviewers. The full text of selected articles was accessed and screened for relevance in more detail. Articles for which the full text could not be accessed, which were not open access and could not be accessed through the University of Liverpool or Lancaster University library subscriptions, were excluded. The bibliographies of the selected articles were searched for additional relevant articles, based on title and full text, subject to the same inclusion and exclusion criteria.

\section{Data collection strategy}

From the final selection of articles, we extracted information regarding the airline passenger data used in each article (Table 1). This information focused on the source, type and validity of data used in the study (Table 1, part A) and the reproducibility of data usage judged by pre-defined criteria (Table 1, part B). For the purposes of this review, data validation was defined as the comparison of primary data used in an article against at least one independent and appropriately comparable set of data. An article was deemed to have validated its data source if it cited another independent and comparable data set and contained a comparison between them. To determine reproducibility, each article was assessed for its reporting of data source using the checklist shown in Table 1, part B and scored accordingly. We did not plan or conduct any bias analysis of the selected publications.

\section{Results}

From the 4,012 articles identified in the search, 2,547 were identified as duplicates and rejected, resulting in 1,465 articles which went forward for title and abstract screening (Figure). A further 1,130 were rejected at this stage as they did not meet the inclusion criteria. A total of 335 articles were selected based on their title and abstract and read in full. From these, 223 were rejected: the majority $(n=87)$ did not contain airline data, 73 were deemed not relevant (did not contain at least two required criteria, such as airline data and model) and 20 used no model. An additional 19 were country-specific, 17 were inaccessible (no access to journal or language barrier), five were reviews and two were not focused on human disease movement. After reading the articles in full, 112 were selected as relevant to this review. Finally, 24 additional articles, not detected by the search but through reading the bibliography of accepted articles, were included after being read in full to determine relevance.

The publication year of the 136 articles selected ranged from 1985 to 2017 , with the largest number of articles $(n=17)$ published in 2016 (Table 2$)$. In the 20 years following the publication by Rvachev and Longini in 1985, the oldest article relevant to this review, only seven relevant articles were published [13-19].

A wide range of data sources have been used for modelling passenger flow between countries; in total 45 distinct sources were identified (Table 3). Commercial or industry data sources were most often used (14 sources, used in 131 articles), followed by governmental data (14 sources, used in 30 articles). Of the commercial data sources, those most often acknowledged were from the International Air Transport Association (IATA) (61 articles) and OAG, an airline industry company specialising in data provision and analysis (38 articles). Some articles used the airline data directly, however, two articles $[17,20]$ used data from one or more articles (see Table 2) and therefore were also thought of as using industry data. Where a database was named from IATA or OAG sources, OAG MAX was the most common ( 5 articles). A range of other industry-orientated data sources were cited, including Diio (airline market information), Amadeus (travel reservations database), Feeyo (a Chinese flight scheduler) and OpenFlights.org (an open-access database of flight records contributed by members of the public). Four articles used passenger surveys such as TravelPac from the United Kingdom's (UK) Office for National Statistics (ONS), and nine articles used tourism surveys (Table 3). Eleven articles used information published by airports, and four other sources were reported (the social media site Twitter, two aircraft manufacturers and EuroStat).

Most data sources contained information about origin and destination $(n=91,67 \%)$ or passenger numbers ( $n=73,54 \%$ ) (Table 4 ). Data pertaining to direct flights only were used more often than data pertaining to full passenger itineraries: $n=33$ and $n=27$, respectively. Of the 62 studies using IATA as a data source, 15 used information of direct flight only $[10,21-34]$ and of the 38 using OAG, 11 used information of direct flight only $[2,23,24,34-41]$. Finally, eight articles [21,22,24,42-46] indirectly used IATA data by using the online modelling tool GLEAMviz [47], and two $[10,48]$ by using BioDisapora (now Bluedot.global [49]).

According to the set of standards we had established to determine an article's reproducibility (see Table 1, part B), no article was considered fully reproducible. Eight $(6 \%)$ articles were deemed partially reproducible (score of 3 or above), where some information regarding the description and use of passenger data was reported [13,50-56]. Of the 45 total data sources identified, 26 were open source, 11 were closed source, and 8 were not publicly available. The date range of the 


\section{TABLE 3A}

Systematic review on airline passenger data in infectious disease modelling, data sources identified in the selected articles, grouped by sector ( $\mathrm{n}=136$ articles)

\begin{tabular}{|c|c|c|}
\hline $\begin{array}{l}\text { Data source (number of uses; percentage of total } \\
\text { uses of any data source) }\end{array}$ & $\begin{array}{l}\text { Number of articles } \\
\text { using data source }\end{array}$ & Reference(s) \\
\hline \multicolumn{3}{|l|}{ Commercial/industry $(n=131 ; 62 \%)$} \\
\hline \multicolumn{3}{|l|}{ International Air Transport Association (IATA) } \\
\hline IATA - unspecified database & 57 & $\begin{array}{c}{[9,10,14-16,20-34,42-46,53,57-61,66,74,75,80-} \\
82,85,88,92,93,97,101,102,109,115^{-} \\
118,123,124,135,136,140,141,151,152\end{array}$ \\
\hline IATA - Air passenger market analysis & 1 & [99] \\
\hline $\begin{array}{l}\text { IATA - Airport intelligence services - passenger } \\
\text { data }\end{array}$ & 1 & [153] \\
\hline IATA - International travel statistics & 1 & [108] \\
\hline IATA - Passenger intelligence services & 1 & [98] \\
\hline \multicolumn{3}{|l|}{ OAG (company specialising in airline industry data) } \\
\hline OAG - Unspecified database & 30 & $\begin{array}{c}{\left[2,15-20,23,24,34^{-}\right.} \\
39,41,43,44,46,66,85,97,115,122,128,136,142,145,146,154]\end{array}$ \\
\hline OAG MAX & 5 & {$[40,83,96,103,127]$} \\
\hline OAG - t 100 database & 2 & {$[65,112]$} \\
\hline OAG - Traffic analyser & 1 & [77] \\
\hline \multicolumn{3}{|l|}{ International Civil Aviation Organization (ICAO) } \\
\hline ICAO - Unspecified database & 11 & {$[17-20,59,89,97,104,115,147,149]$} \\
\hline ICAO - Traffic by flight stage & 1 & [15] \\
\hline Air transport statistics & 3 & {$[18-20]$} \\
\hline Airports Council International (ACI) & 1 & [117] \\
\hline Amadeus & 1 & [110] \\
\hline BACK Aviation Solutions Incorporated & 4 & {$[15,20,97,115]$} \\
\hline CapStat & 1 & [132] \\
\hline Diio & 3 & {$[105,111,113]$} \\
\hline Feeyo & 1 & {$[52]$} \\
\hline Landings.com & 1 & [110] \\
\hline OpenFlights.org & 4 & {$[64,120,130,131]$} \\
\hline OurAirports.com & 1 & {$[64]$} \\
\hline \multicolumn{3}{|l|}{ Tourism surveys ( $\mathrm{n}=9 ; 4 \%)$} \\
\hline Icelandic Tourist Board & 1 & [56] \\
\hline Singapore Tourism Board & 1 & [144] \\
\hline $\begin{array}{l}\text { Turism.se (Swedish tourist and travel commercial } \\
\text { database) }\end{array}$ & 1 & [13] \\
\hline World Tourism Organization (UNWTO) & 5 & {$[95,107,134,150,155]$} \\
\hline $\begin{array}{l}\text { United States Office of Travel and Tourism } \\
\text { Industries }\end{array}$ & 1 & [41] \\
\hline \multicolumn{3}{|l|}{ National passenger surveys $(n=4 ; 2 \%)$} \\
\hline Brazilian Ministry of Tourism & 1 & [95] \\
\hline United Kingdom Office for National Statistics & 3 & {$[107,134,138]$} \\
\hline \multicolumn{3}{|l|}{ Airport-published information $(n=12 ; 6 \%)$} \\
\hline Amsterdam Airport (Schiphol) & 1 & [79] \\
\hline Beijing Capital International Airport & 2 & {$[108,109]$} \\
\hline $\begin{array}{l}\text { German airports (Hannover, Frankfurt, Hamburg, } \\
\text { Munich) }\end{array}$ & 1 & [79] \\
\hline Helsinki Airport & 1 & [79] \\
\hline Hong Kong International Airport & 2 & {$[108,109]$} \\
\hline Keflavik Airport & 1 & [56] \\
\hline $\begin{array}{l}\text { London airports (Heathrow, Gatwick, Stansted, } \\
\text { Luton) }\end{array}$ & 1 & [79] \\
\hline Madeira Airport & 1 & [121] \\
\hline Teheran Airport & 1 & [79] \\
\hline Venice Airport & 1 & [79] \\
\hline
\end{tabular}

${ }^{a}$ An article may have included more than one pathogen. 
TABLE 3B

Systematic review on airline passenger data in infectious disease modelling, data sources identified in the selected articles, grouped by sector $(\mathrm{n}=136$ articles)

\begin{tabular}{|c|c|c|}
\hline $\begin{array}{l}\text { Data source (number of uses; percentage of total } \\
\text { uses of any data source) }\end{array}$ & $\begin{array}{l}\text { Number of articles } \\
\text { using data source }\end{array}$ & Reference(s) \\
\hline \multicolumn{3}{|l|}{ Government-published information ( $n=33 ; 15 \%)$} \\
\hline United States Department of Transport & 14 & {$[15,20,54,62-65,84,97,100,112,115,133,148]$} \\
\hline Australian Department of Transport & 2 & {$[18,19]$} \\
\hline Australian International Airport Traffic & 4 & {$[15,18-20]$} \\
\hline Brazilian Ministry of Tourism & 1 & [126] \\
\hline Department of Tourism of Thailand & 1 & [139] \\
\hline Hong Kong Tourism Board & 1 & [91] \\
\hline Japan National Tourism Organization & 1 & [55] \\
\hline Malaysian Department of Statistics & 1 & [78] \\
\hline Mexican Secretary Communication and Transport & 1 & [106] \\
\hline National Statistics China & 1 & [104] \\
\hline General Authority Of Civil Aviation of Saudi Arabia & 1 & [117] \\
\hline Singapore tourism sector performance & 1 & [125] \\
\hline Statistics Canada & 1 & [119] \\
\hline Statistics Iceland & 1 & [56] \\
\hline United Kingdom civil aviation authorities & 2 & {$[50,86]$} \\
\hline \multicolumn{3}{|l|}{ Other sources $(n=11 ; 5 \%)$} \\
\hline Airbus Industries & 3 & {$[15,20,97]$} \\
\hline Boeing Corporation & 3 & {$[15,20,97]$} \\
\hline EuroStat & 4 & {$[59,100,129,137]$} \\
\hline Twitter & 1 & [51] \\
\hline Unclear or unreported $(n=13 ; 6 \%)$ & 13 & {$[15,18-20,48,87,90,94,97,114,119,127,143]$} \\
\hline
\end{tabular}

a An article may have included more than one pathogen.

data (start and end date) was reported in $58 \%(n=79)$ studies, and an access date was stated in $25 \%(n=34)$ of the sources used. Data validation as previously defined was performed in $5 \%(n=7)$ of the articles $[13,34,46,51,57-59]$. Only 40 articles (29\%) reported performing any data cleaning or manipulation before using the data set.

The majority of articles ( $n=115 ; 85 \%$ ) were concerned with the global spread of infectious diseases, while the analysis of the airline network itself (while modelling pathogen spread) was the next most common purpose $(n=11 ; 8 \%)$. Five articles used passenger data for descriptive or illustrative purposes $[13,29,30,60,61]$, two articles used the data for passenger screening simulations $[62,63]$ and two articles described the development of a public health tool [23,64]. Of the pathogens modelled, pandemic influenza was the most frequent subject of the models $(n=40 ; 29 \%)$ (Table 5$)$. Generic models not focussing on a specific pathogen were also common $(n=23 ; 17 \%)$.

\section{Discussion}

The purpose of this review was to assess the source and usage of airline passenger data used in mathematical models of international infectious disease spread. A total of 136 articles met the inclusion criteria, from which we identified 45 unique data sources.

The majority of these were sources provided on a commercial basis, e.g. IATA, OAG and the International Civil Aviation Organization (ICAO). These commercial sources provide information from the aviation industry for use within that industry and are marketed as being detailed and accurate. The data resolution can be high: for example, passenger data are available stratified by route (including stopovers), fare class, point of origin and time period. There are often restrictions on the use of the data, in particular non-disclosure agreements regarding the data, collection and retrieval methods, and financial charges apply for access [7]. This type of data is essentially closed data: publicly available but with restricted access. Furthermore, the methodology underpinning data collection is generally undisclosed and it is therefore difficult for researchers to assess the quality, representability and biases of the data. Although these data sources may have a number of subsets representing different data types, authors rarely provide more accurate reporting of the data sets, including name of subsets used and date of access, 
Systematic review on airline passenger data in infectious disease modelling, frequency of use of each data type identified $(\mathrm{n}=136$ articles)

\begin{tabular}{|l|c|c|c|}
\hline \multirow{2}{*}{ Data type $^{\mathrm{a}}$} & \multicolumn{2}{|c|}{$\begin{array}{c}\text { Number of articles } \\
\text { using data type }\end{array}$} & References \\
\cline { 2 - 3 } & $\mathrm{n}$ & $\%$ & \\
\hline $\begin{array}{l}\text { Includes information on } \\
\text { origin and destination }\end{array}$ & 91 & 67 & $\begin{array}{c}{[2,9,10,13-16,21,23-26,30,31,34,35,37-42,44,46,48,53-56,58,59,64,66,74,75,77,79,81-} \\
83,85,86,88-90,92,93,95,96,98-101,104-107,110-113,116-118,120,122-124,127,130-133,135- \\
141,145-155]\end{array}$ \\
\hline Passenger numbers & 74 & 54 & $\begin{array}{c}{[2,9,10,13-16,25,29,31,34,37,41,45,48,50,53-56,58,59,62-64,74,75,77,79,82,84,86-} \\
90,94,95,98-101,104-109,113,116,117,123-126,132-135,137,139-141,144-153,155]\end{array}$ \\
\hline Direct flights only & 33 & 24 & {$[2,10,21-41,54,59,64,79,89,104,111,113,120,137]$} \\
\hline Full itinerary & 27 & 20 & $\begin{array}{r}{[10,25,34,53,58,59,61,74,75,81,83,88,98,99,101,112,116,118,123,130,136,140,141,146,152-} \\
154]\end{array}$ \\
\hline Unreported or unclear & 25 & 18 & {$[15,17-20,43,51,57,64,65,78,80,91,97,102,109,114,115,119,121,126,127,129,138,143]$} \\
\hline Seat capacity & 24 & 18 & {$[21-24,26-28,31,32,35,36,38,40,41,44,46,60,66,93,111,120,122,142,154]$} \\
\hline Flight numbers & 13 & 10 & {$[36,39,62,63,83,85,96,103,106,110,127,128,131]$} \\
\hline Tickets sold & 3 & 2 & {$[52,64,81]$} \\
\hline
\end{tabular}

${ }^{a}$ An article may have included multiple data types.

among other criteria. An additional complication is that customers of the same data provider may receive different data depending on the timing, exact parameters of their database query and their subscription levels.

A number of data sources identified in the review were open-access and include aggregate numbers of passenger published by individual airports, data compiled and released by government agencies (e.g. the UK Office for National Statistics) and information derived from tourism surveys. Although freely available to access, these data sets may not provide the resolution of information required by modelling studies as they typically are limited to passengers departing from or arriving at a specific geographical region or are aggregated over long time periods (annual or quarterly data). In addition, the collection methodology is not always reported for such data sources and there may be biases in the data particularly where reporting is voluntary. Combining information from such sources represents a considerable data challenge.

International travel data describing direct flights only were used more often than those with full itinerary information. Data based on direct flights exclude information on connecting passengers and will therefore underestimate the number of passengers travelling to a specific destination. This limitation is likely to introduce bias, underestimating passenger flow between distant or poorly served locations and overestimating passengers travelling shorter distances [65]. This bias has implications for public health planning as some locations or countries may have an apparent lower risk of importation events because of the lack of direct flights from putative infecting source countries. This may explain the discrepancy during the Ebola epidemic in West Africa in 2014 and 2015, where several studies suggested that the United States (US) was at relatively low risk of importation following the suspension of direct flights. The US did however receive two importations through air travel from the affected area, one was due to a passenger reaching their final destination through indirect flights and the second was a returning healthcare worker $[25,66,67]$.

When considering international travel patterns for public health purposes, accessing information on the number of passengers travelling from an origin to a destination is the most relevant. However, we found that several articles used data for which the unit of measurement was not number of passengers but described passenger traffic in terms of seat capacity - the number of seats on aircraft flying between two specific airports - for which assumptions must be made regarding how full individual flights are and how this may or may not vary with season. In addition, this data type cannot take into account the full routing of a passenger and this information must therefore be inferred from the data or the study needs to state that only direct flights were considered. The variety of data types used for epidemic modelling purposes perhaps reflects the lack of a widely accepted and accessible data source, and this variation in data unit could lead to differences in the conclusions between modelling studies.

To ensure reproducibility by others, studies should report information regarding the source and type of data used, the date of access and any cleaning or manipulation conducted. Our analysis showed that this standard is rarely attained. Reporting the date of access (and date of data extraction if different) is important as several data-providing companies update their data monthly, with retrospective adjustments of values [68]. Few studies reported the date of access to or extraction of the data set. Acknowledging any data cleaning or manipulation is also important for reproducibility [69]: 
TABLE 5

Systematic review on airline passenger data in infectious disease modelling, pathogens modelled in the selected articles $(\mathrm{n}=136)$

\begin{tabular}{|c|c|c|c|}
\hline \multirow[t]{2}{*}{ Pathogen ${ }^{a}$} & \multicolumn{2}{|c|}{$\begin{array}{l}\text { Number of articles } \\
\text { modelling pathogen }\end{array}$} & \multirow[t]{2}{*}{ References } \\
\hline & $\mathrm{n}$ & $\%$ & \\
\hline $\begin{array}{l}\text { Generic model (no specific } \\
\text { pathogen) }\end{array}$ & 23 & 17 & {$[20-22,27,28,30,31,35,36,40,48,57,61,65,80,102,103,109,128,137,138,143,149]$} \\
\hline Chikungunya virus & 6 & 4 & {$[41,59,75,88,113,132]$} \\
\hline Vibrio cholerae & 1 & 1 & {$[64]$} \\
\hline Clostridium difficile & 1 & 1 & [60] \\
\hline Dengue virus & 17 & 13 & {$[10,34,53,55,59,74,89,100,101,121,125,126,132,139,144,147,152]$} \\
\hline Ebola virus & 7 & 5 & {$[25,44,66,77,136,142,154]$} \\
\hline Hepatitis A virus & 1 & 1 & [84] \\
\hline $\begin{array}{l}\text { Human immunodeficiency } \\
\text { virus }\end{array}$ & 1 & 1 & [78] \\
\hline Influenza virus - pandemic & 40 & 29 & $\begin{array}{c}{\left[2,14^{-}\right.} \\
19,23,24,26,32,38,39,42,46,52,54,58,62,63,79,87,90,91,93,96,97,106,108,110,111,115^{-} \\
117,119,120,122,129,148,155]\end{array}$ \\
\hline Influenza virus - seasonal & 7 & 5 & {$[50,51,56,84,114,127,133]$} \\
\hline Japanese encephalitis virus & 1 & 1 & {$[107]$} \\
\hline $\begin{array}{l}\text { Plasmodium parasite } \\
\text { species }\end{array}$ & 5 & 4 & {$[41,84,94,134,146]$} \\
\hline Measles virus & 1 & 1 & [153] \\
\hline $\begin{array}{l}\text { Middle East respiratory } \\
\text { syndrome coronavirus }\end{array}$ & 7 & 5 & {$[33,37,45,99,118,131,135]$} \\
\hline Poliovirus & 1 & 1 & [151] \\
\hline $\begin{array}{l}\text { Severe acute respiratory } \\
\text { syndrome }\end{array}$ & 6 & 4 & {$[29,83,85,92,104,141]$} \\
\hline Smallpox virus & 1 & 1 & [43] \\
\hline $\begin{array}{l}\text { Salmonella } \\
\text { entericaserotypes Typhi and } \\
\text { Paratyphi }\end{array}$ & 1 & 1 & {$[13]^{*}$} \\
\hline Vector importation & 1 & 1 & [145] \\
\hline West Nile virus & 1 & 1 & {$[86]$} \\
\hline Yellow fever virus & 3 & 2 & {$[95,112,150]$} \\
\hline Zika virus & 9 & 7 & {$[9,81,82,98,105,123,124,130,140]$} \\
\hline
\end{tabular}

a An article may have included more than one pathogen.

for example, if the authors are considering passengers departing or arriving from cities rather than airports but the data were collected at the airport level, the aggregation of passenger numbers from each airport to the city should be acknowledged by the authors. For additional clarity, it would be useful if the authors reported the stage at which the data was aggregated to city level, whether this was part of the original data, or if this was a data manipulation done by the authors. At the time of writing of this review, there was limited understanding of the sensitivity of this level of data (city level) and how it compares to airport-level data and other aggregated data sets, requiring further analytical work. Overall, the majority of articles were deemed to have methods that were not reproducible, and while eight studies were deemed partially reproducible, none were considered to be fully reproducible. It is incumbent on authors to ensure accurate reporting for all aspects of their methodology; our findings suggest that authors of international disease modelling studies should aim to improve their reporting of source and usage of airline passenger data. We advise authors to reference the fields reported in Table 1 , part $B$, at a minimum, when using any data sets.

Data validation is often required to ensure that the collected data are free from biases and an accurate reflection of the subject or process they describe. For airline passenger data, validation is particularly important if the passenger data are sourced from a commercial company with limited or no collection methodology disclosed. Only seven articles reported validation with at least one independent or appropriately comparable set of observations. While there is no acknowledged gold standard data set, governmental open source data, such as those from the US Department of Transport or 
Travelpac, do at least have published methodology on which potential biases may be identified.

Many pathogens can be relocated through human movement to populations where susceptibility or a lack of awareness may afford a greater incidence and persistence. Most articles reviewed, where a specific pathogen was considered, investigated transmission or importation of viruses. Only three articles were focused on bacteria (Vibrio cholera, Clostridium difficile and Salmonella enterica serotypes Typhi and Paratyphi), despite the known importance of international travel for the global dissemination of antibacterial resistance $[70,71]$ and the capacity of bacteria to initiate epidemics following importation, e.g. the cholera outbreak on Haiti in 2010 [72]. Pandemic influenza was the disease most often considered by the reviewed articles, which perhaps reflects the global significance of pandemic events and the ease with which pandemic strains have spread historically. The other non-influenza viruses noted in these studies have all initiated outbreaks following introduction through international travel. Outbreaks following introduction occurred in South Korea with MERS Co-V [73], in the Portuguese islands of Madeira (off the coast of Western Africa) with dengue virus [74] and in the Caribbean (leading to imported cases in the US) and Italy with chikungunya virus $[75,76]$. Finally, the accurate modelling of importation risks for specific pathogens may require very high-resolution passenger data, particularly where routes are indirect and the total travel time from origin to destination is important for screening, taking incubation periods into account [77].

To the best of our knowledge, direct comparisons of commercial with open-access data sets, or between commercial data sets, have not yet been accomplished, preventing an informed decision on which data sets are more suitable to represent airline passengers. Although a direct comparison between commercial data sets is likely to be informative for the modelling community, it is also likely to be expensive. In addition, the presence of a single data set that is agreed by the community to be the best representation of international (and national) airline passenger flow would be ideal, although it may be difficult to realise given proprietorial restrictions of certain data sets. The field should aspire to collaborate with industrial data providers to make accurate passenger data available for research, particularly during global public health emergencies.

\section{Strengths and limitations of the review}

The screening and selection of articles was done in a systematic manner and by two independent reviewers to ensure all relevant articles were included in the selection of articles to be read in full. The full reference lists of accepted articles were read to find additional relevant articles. Although a number of articles were found when going through reference lists, we are confident that this selection was a good representation of the range of airline data used. In addition, no other review that we are aware of is focused on the analysis of the validity and reproducibility of the data used for mathematical models of infectious disease spread by air travel. Limitations of this study include not contacting authors regarding their methods and not including other search engines which may have yielded additional articles but would also have returned a very large number of potential articles to process. In addition, by limiting the articles to international spread only, some articles which focused primarily on spread within a country were excluded, even though they may include relevant data sources.

\section{Conclusion}

We conducted a systematic review to assess the range and reporting of data used by authors to model the international spread of infectious diseases through the airline network. We found 136 articles matching our inclusion criteria and extracted information regarding source, data type, validation assessment and reproducibility. We found a variety of data sources and types used, limited validation performed and poor reporting, rendering many studies unreproducible. We recommend that greater effort is devoted to validation and data sources and that a consensus is achieved on the use of information sources providing airline passenger data. Public health modelling would benefit greatly from the availability of a validated contemporary opensource data source which includes detailed origin-destination information, including connecting passengers, and has high temporal resolution.

\begin{abstract}
${ }^{*}$ Note added in proof
During editing following acceptance, the authors became aware of a further four articles that satisfied inclusion criteria but were not discoverable using the search algorithm (De Jong B, Ekdahl K. BMC Public Health. 2006 Dec;6(1):4. Ekdahl K, Andersson Y. BMC Infect Dis. 2004 Dec;4(1):54. Ekdahl K, Andersson Y. Am J Trop Med Hyg. 2005;72(6):825-30. Ekdahl K, Andersson Y. J Infect. 2005;51(3):222-9). The articles all utilised a previously identified data source (Turism.se) and modelled the travel-related risk of campylobacteriosis, giardiasis, salmonellosis and shigellosis infection. This omission affects quantitative elements of Tables 3 to 5 , but does not affect our results and conclusions regarding data sources, nor our overall conclusions and recommendations.
\end{abstract}

\section{Acknowledgements}

The research was funded by the National Institute for Health Research Health Protection Research Unit (NIHR HPRU) in Emerging and Zoonotic Infections at University of Liverpool in partnership with Public Health England (PHE), in collaboration with Liverpool School of Tropical Medicine. Margaux Mesle is based at The University of Liverpool. IMH is also supported by the PANDHUB project from the European Union Seventh Framework Programme under grant agreement no. 607433. The views expressed are those of the author(s) and not necessarily those of the NHS, the NIHR, the Department of Health or Public Health England. The authors would like to thank Dr Caroline Walters for her feedback on working drafts of the manuscript. 


\section{Conflict of interest}

None declared.

\section{Authors' contributions}

JMR, RMC, IMH, SL and MMIM conceived and designed the study and methods.

MMIM performed the literature search.

MMIM, JMR and IMH reviewed and selected articles.

MMIM extracted and analysed data.

MMIM and JMR prepared the first draft of the manuscript.

All authors provided comments on and edited the manuscript.

\section{References}

1. Wilder-Smith A. The severe acute respiratory syndrome: impact on travel and tourism. Travel Med Infect Dis, 2006:4(2):53-60. https://doi.org/10.1016/j.tmaid.2005.04.004 PMID: 16887725

2. Fraser C, Donnelly CA, Cauchemez S, Hanage WP, Van Kerkhove MD, Hollingsworth TD, et al. Pandemic potential of a strain of influenza $A\left(\mathrm{H}_{1} \mathrm{~N}_{1}\right)$ : early findings. Science. 2009;324(5934):1557-61. https://doi.org/10.1126/ science.1176062 PMID: 19433588

3. Al Hajjar S, McIntosh K. The first influenza pandemic of the 21st century. Ann Saudi Med. 2010;30(1):1-10. https://doi. org/10.5144/0256-4947.59365 PMID: 20103951

4. Glaesser D, Kester J, Paulose H, Alizadeh A, Valentin B. Global travel patterns: an overview. J Travel Med. 2017;24(4). https:// doi.org/10.1093/jtm/tax007 PMID: 28637267

5. Saker L, Lee K, Cannito B, Gilmore A, Campbell-Lendrum D. Globalization and infectious diseases: a review of the linkages. Geneva: World Health Organization; 2004. Available from: https://www.who.int/tdr/publications/documents/seb_topic3. pdf

6. World Tourism Organisation (UNWTO). Exports from international tourism rise $4 \%$ in 2015 . Madrid: UNWTO; 2016. Available from: http:// media.unwto.org/press-release/2016-05-03/ exports-international-tourism-rise-4-2015

7. Mao L, Wu X, Huang Z, Tatem AJ. Modeling monthly flows of global air travel passengers: An open-access data resource. J Transp Geogr. 2015;48:52-60. https://doi.org/10.1016/j. jtrange0.2015.08.017

8. Lopez LF, Amaku M, Coutinho FA, Quam M, Burattini MN Struchiner CJ, et al. Modeling importations and exportations of infectious diseases via travelers. Bull Math Biol. 2016;78(2):185-209. https://doi.org/10.1007/s11538-015-0135-z PMID: 26763222

9. Quam MB, Wilder-Smith A. Estimated global exportations of Zika virus infections via travellers from Brazil from 2014 to 2015. J Travel Med. 2016;23(6):taw059. https://doi. org/10.1093/jtm/taw059 PMID: 27601533

10. Quam MB, Khan K, Sears J, Hu W, Rocklöv J, Wilder-Smith A. Estimating air travel-associated importations of dengue virus into Italy. J Travel Med. 2015;22(3):186-93. https://doi. org/10.1111/jtm.12192 PMID: 25756472

11. Quam MB, Wilder-Smith A. Importation index of dengue to determine the most probable origin of importation. J Travel Med. 2015;22(1):72. https://doi.org/10.1111/jtm.12177 PMID: 25560231

12. Huang Z, Wu X, Garcia AJ, Fik TJ, Tatem AJ. An open-access modeled passenger flow matrix for the global air network in 2010. PLoS One. 2013;8(5):e64317. https://doi.org/10.1371/ journal.pone.0064317 PMID: 23691194

13. Ekdahl K, de Jong B, Andersson Y. Risk of travelassociated typhoid and paratyphoid fevers in various regions. J Travel Med. 2005;12(4):197-204. https://doi. org/10.2310/7060.2005.12405 PMID: 16086894

14. Flahault A, Deguen S, Valleron AJ. A mathematical model for the European spread of influenza. Eur J Epidemiol. 1994;10(4):471-4. https://doi.org/10.1007/BF01719679 PMID: 7843359
15. Grais RF, Ellis JH, Glass GE. Assessing the impact of airline travel on the geographic spread of pandemic influenza. Eur J Epidemiol. 2003;18(11):1065-72. https://doi. org/10.1023/A:1026140019146 PMID: 14620941

16. Hufnagel L, Brockmann D, Geisel T. Forecast and control of epidemics in a globalized world. Proc Natl Acad Sci U S A. 2004;101(42):15124-9. https://doi.org/10.1073/ pnas.0308344101 PMID: 15477600

17. Longini IM Jr. A mathematical model for predicting the geographic spread of new infectious agents. Math Biosci. 1988;90:367-83.

18. Longini IM Jr, Fine PE, Thacker SB. Predicting the global spread of new infectious agents. Am I Epidemiol. 1986;123(3):383-91. https://doi.org/10.1093/oxfordjournals.aje.a114253 PMID: 3946385

19. Rvachev L, Longini IM Jr. A mathematical model for the global spread of influenza. Math Biosci. 1985;75(1):3-22. https://doi. org/10.1016/0025-5564(85)90064-1

20. Daniel WB, Hengartner NW, Rivera MK, Powell DR, McPherson TN. An epidemiological model of spatial coupling for trips longer than the infectious period. Math Biosci. 2013;242(1):1-8. https://doi.org/10.1016/j.mbs.2012.11.002 PMID: 23246512

21. Balcan D, Colizza V, Gonçalves B, Hu H, Ramasco JJ, Vespignani A. Multiscale mobility networks and the spatial spreading of infectious diseases. Proc Natl Acad Sci U S A. 2009;106(51):21484-9. https://doi.org/10.1073/ pnas.0906910106 PMID: 20018697

22. Ajelli M, Gonçalves B, Balcan D, Colizza V, Hu H, Ramasco J, et al. Comparing large-scale computational approaches to epidemic modeling: agent-based versus structured metapopulation models. BMC Infect Dis. 2010;10:190. https:// doi.org/10.1186/1471-2334-10-190 PMID: 20587041

23. Balcan D, Gonçalves B, Hu H, Ramasco JJ, Colizza V, Vespignani A. Modeling the spatial spread of infectious diseases: the GLobal Epidemic and Mobility computational model. J Comput Sci. 2010;1(3):132-45. https://doi.org/10.1016/j. jocs.2010.07.002 PMID: 21415939

24. Balcan D, Hu H, Goncalves B, Bajardi P, Poletto C, Ramasco JJ, et al. Seasonal transmission potential and activity peaks of the new influenza $\mathrm{A}\left(\mathrm{H}_{1} \mathrm{~N}_{1}\right)$ : a Monte Carlo likelihood analysis based on human mobility. BMC Med. 2009;7:45. https://doi. org/10.1186/1741-7015-7-45 PMID: 19744314

25. Bogoch II, Creatore MI, Cetron MS, Brownstein JS, Pesik N, Miniota J, et al. Assessment of the potential for international dissemination of Ebola virus via commercial air travel during the 2014 west African outbreak. Lancet. 2015;385(9962):2935. https://doi.org/10.1016/S0140-6736(14)61828-6 PMID: 25458732

26. Colizza V, Barrat A, Barthelemy M, Valleron AJ, Vespignani A. Modeling the worldwide spread of pandemic influenza: baseline case and containment interventions. PLoS Med. 2007;4(1):e13. https://doi.org/10.1371/journal.pmed.0040013 PMID: 17253899

27. Colizza V, Barrat A, Barthélemy M, Vespignani A. The modeling of global epidemics: stochastic dynamics and predictability. Bull Math Biol. 2006;68(8):1893-921. https://doi.org/10.1007/ S11538-006-9077-9 PMID: 17086489

28. Colizza V, Barrat A, Barthélemy M, Vespignani A. The role of the airline transportation network in the prediction and predictability of global epidemics. Proc Natl Acad Sci U S A. 2006;103(7):2015-20. https://doi.org/10.1073/ pnas.0510525103 PMID: 16461461

29. Colizza V, Barrat A, Barthelemy M, Vespignani A. Epidemic predictions and predictability in complex environments. Biophys Rev Lett. 2008;3(1):217-26. https://doi.org/10.1142/ S1793048008000708

30. Colizza V, Barthélemy M, Barrat A, Vespignani A. Epidemic modeling in complex realities. C R Biol. 2007;330(4):364-74 https://doi.org/10.1016/j.crvi.2007.02.014 PMID: 17502293

31. Colizza V, Vespignani A. Epidemic modeling in metapopulation systems with heterogeneous coupling pattern: theory and simulations. J Theor Biol. 2008;251(3):450-67. https://doi. org/10.1016/j.jtbi.2007.11.028 PMID: 18222487

32. Hosseini P, Sokolow SH, Vandegrift KJ, Kilpatrick AM, Daszak P. Predictive power of air travel and socio-economic data for early pandemic spread. PLoS One. 2010;5(9):e12763. https://doi. org/10.1371/journal.pone.0012763 PMID: 20856678

33. Poletto C, Pelat C, Levy-Bruhl D, Yazdanpanah Y, Boelle PY, Colizza V. Assessment of the Middle East respiratory syndrome coronavirus (MERS-CoV) epidemic in the Middle East and risk of international spread using a novel maximum likelihood analysis approach. Euro Surveill. 2014;19(23):20824. https:// doi.org/10.2807/1560-7917.ES2014.19.23.20824 PMID: 24957746 
34. Sessions OM, Khan K, Hou Y, Meltzer E, Quam M, Schwartz $\mathrm{E}$, et al. Exploring the origin and potential for spread of the dengue outbreak in Luanda, Angola. Glob Heal Action. 2013;6:21822. http://dx.doi.org/ https://doi.org/10.3402/gha. v6io.21822 PMID: 23911088

35. Bobashev G, Morris RJ, Goedecke DM. Sampling for global epidemic models and the topology of an international airport network. PLoS One. 2008;3(9):e3154. https://doi.org/10.1371/ journal.pone.0003154 PMID: 18776932

36. Brockmann D, Helbing D. The hidden geometry of complex, network-driven contagion phenomena. Science. 2013;342(6164):1337-42. https://doi.org/10.1126/ science.1245200 PMID: 24337289

37. Carias C, O’Hagan JJ, Jewett A, Gambhir M, Cohen NJ, Haber $Y$, et al. Exportations of symptomatic cases of MERS-CoV infection to countries outside the Middle East. Emerg Infect Dis. 2016;22(4):723-5. https://doi.org/10.3201/ eid2204.150976 PMID: 27358972

38. Lemey P, Rambaut A, Bedford T, Faria N, Bielejec F, Baele G, et al. Unifying viral genetics and human transportation data to predict the global transmission dynamics of human influenza H3N2. PLoS Pathog. 2014;10(2):e1003932. https://doi. org/10.1371/journal.ppat.1003932 PMID: 24586153

39. Marcelino J, Kaiser $\mathrm{M}$. Reducing in $\mathrm{fl}$ uenza spreading over the airline network. PLoS Curr. 2009;1:RRN1005. PMID: 20020673

40. Tatem AJ, Hay SI. Climatic similarity and biological exchange in the worldwide airline transportation network. Proc Biol Sci. 2007;274(1617):1489-96. https://doi.org/10.1098/ rspb.2007.0148 PMID: 17426013

41. Tatem AJ, Huang Z, Das A, Qi Q, Roth J, Qiu Y. Air travel and vector-borne disease movement. Parasitology. 2012;139(14):1816-30. https://doi.org/10.1017/ So031182012000352 PMID: 22444826

42. Bajardi P, Poletto C, Ramasco JJ, Tizzoni M, Colizza V, Vespignani A. Human mobility networks, travel restrictions, and the global spread of $2009 \mathrm{H}_{1} \mathrm{~N}_{1}$ pandemic. PLoS One. 2011;6(1):e16591. https://doi.org/10.1371/journal. pone.0016591 PMID: 21304943

43. Gonçalves B, Balcan D, Vespignani A. Human mobility and the worldwide impact of intentional localized highly pathogenic virus release. Sci Rep. 2013;3:810. https://doi.org/10.1038/ srepoo810 PMID: 23860371

44. Pastore-Piontti A, Zhang Q, Gomes MFC, Rossi L, Poletto C, Colizza V. Real-time assessment of the international spreading risk associated with the West African Ebola outbreak. In: Chowell G, Hyman J, eds. Mathematical and statistical modeling for emerging and re-emerging infectious diseases. Springer, Cham; 2016. Available from: https://link.springer. com/chapter/10.1007/978-3-319-40413-4_4

45. Poletto C, Colizza V, Boëlle P-Y. Quantifying spatiotemporal heterogeneity of MERS-CoV transmission in the Middle East region: A combined modelling approach. Epidemics. 2016;15:19. https://doi.org/10.1016/j.epidem.2015.12.001 PMID: 27266844

46. Tizzoni M, Bajardi P, Poletto C, Ramasco JJ, Balcan D, Gonçalves B, et al. Real-time numerical forecast of global epidemic spreading: case study of $2009 \mathrm{~A} / \mathrm{H} 1 \mathrm{~N} 1 \mathrm{pdm}$. BMC Med. 2012;10(1):165. https://doi.org/10.1186/1741-7015-10-165 PMID: 23237460

47. The Global Epidemic and Mobility Model (GLEAMviz). [Accessed: 28 Mar 2017]. Available from: http://www.gleamviz. org/

48. Khan K, Freifeld CC, Wang J, Mekaru SR, Kossowsky D, Sonricker AL, et al. Preparing for infectious disease threats at mass gatherings: the case of the Vancouver 2010 Olympic Winter Games. CMAJ. 2010;182(6):579-83. https://doi. org/10.1503/cmaj.100093 PMID: 20181726

49. BlueDot. [Accessed: 18 Feb 2018]. Available from: https:// bluedot.global

50. Bedford T, Riley S, Barr IG, Broor S, Chadha M, Cox NJ, et al. Global circulation patterns of seasonal influenza viruses vary with antigenic drift. Nature. 2015;523(7559):217-20. https:// doi.org/10.1038/nature14460 PMID: 26053121

51. Brennan S, Sadilek A, Kautz H. Towards understanding global spread of disease from everyday interpersonal interactions. In: Proceedings of the Twenty-Third International Joint Conference on Artificial Intelligence (IJCAI). Beijing, China, 3-9 August 2013:2783-2789.

52. Chang C, Cao C, Wang Q, Chen Y, Cao Z, Zhang H, et al. The novel $\mathrm{H}_{1} \mathrm{~N}_{1}$ influenza A global airline transmission and early warning without travel containments. Chin Sci Bull. 2010;55(26):3030-6. https://doi.org/10.1007/ S11434-010-3180-X

53. Gardner L, Sarkar S. A global airport-based risk model for the spread of dengue infection via the air transport network.
PLoS One. 2013;8(8):e72129. https://doi.org/10.1371/journal. pone.0072129 PMID: 24009672

54. Gardner LM, Fajardo D, Waller ST. Inferring InfectionSpreading Links in an Air Traffic Network. Transp Res Rec. 2012;2300(1):13-21. https://doi.org/10.3141/2300-02

55. Quam MB, Sessions O, Kamaraj US, Rocklöv J, Wilder-Smith A. Dissecting Japan's dengue outbreak in 2014. Am J Trop Med Hyg. 2016;94(2):409-12. https://doi.org/10.4269/ ajtmh.15-0468 PMID: 26711518

56. Weinberger DM, Krause TG, Mølbak K, Cliff A, Briem H, Viboud $C$, et al. Influenza epidemics in Iceland over 9 decades: changes in timing and synchrony with the United States and Europe. Am J Epidemiol. 2012;176(7):649-55. https://doi. org/10.1093/aje/kwS140 PMID: 22962250

57. Gautreau A, Barrat A, Barthélemy M. Global disease spread: statistics and estimation of arrival times. J Theor Biol. 2008;251(3):509-22. https://doi.org/10.1016/j.jtbi.2007.12.001 PMID: 18222486

58. Khan K, Eckhardt R, Brownstein JS, Naqvi R, Hu W, Kossowsky $D$, et al. Entry and exit screening of airline travellers during the $A\left(\mathrm{H}_{1} \mathrm{~N}_{1}\right) 2009$ pandemic: a retrospective evaluation. Bull World Health Organ. 2013;91(5):368-76. https://doi.org/10.2471/ BLT.12.114777 PMID: 23678200

59. Seyler T, Grandesso F, Le Strat Y, Tarantola A, Depoortere $E$. Assessing the risk of importing dengue and chikungunya viruses to the European Union. Epidemics. 2009;1(3):17584. https://doi.org/10.1016/j.epidem.2009.06.003 PMID: 21352765

6o. Clements AC, Magalhães RJ, Tatem AJ, Paterson DL, Riley TV. Clostridium difficile PCR ribotype 027: assessing the risks of further worldwide spread. Lancet Infect Dis. 2010;10(6):395404. https://doi.org/10.1016/S1473-3099(10)70080-3 PMID: 20510280

61. Khan K, McNabb SJ, Memish ZA, Eckhardt R, Hu W, Kossowsky $D$, et al. Infectious disease surveillance and modelling across geographic frontiers and scientific specialties. Lancet Infect Dis. 2012;12(3):222-30. https://doi.org/10.1016/S14733099(11)70313-9 PMID: 22252149

62. Brigantic R, Malone J, Muller G, Lee R, Kulesz J, Delp W, et al. Simulation to assess the efficacy of US airport entry screening of passengers for pandemic influenza. Int J Risk Assess Manag. 2009;12(2/3/4):290-310. https://doi.org/10.1504/ IJRAM.2009.025924

63. Malone JD, Brigantic R, Muller GA, Gadgil A, Delp W, McMahon BH, et al. U.S. airport entry screening in response to pandemic influenza: modeling and analysis. Travel Med Infect Dis. 2009;7(4):181-91. https://doi.org/10.1016/j. tmaid.2009.02.006 PMID: 19717097

64. Corley CD, Lancaster MJ, Brigantic RT, Kunkel BM, Muller G, McKenzie TK. Outside the continental United States international travel and contagion impact quick look tool. Proceedings of the First ACM SIGSPATIAL International Workshop on Use of GIS in Public Health. Redondo Beach, California, 6-9 November 2012. HealthGIS '12.2012:81-86. https://doi.org/http://dx.doi.org/10.1145/2452516.2452533

65. Johansson MA, Arana-Vizcarrondo N, Biggerstaff BJ, Staples JE, Gallagher N, Marano N. On the treatment of airline travelers in mathematical models. PLoS One. 2011;6(7):e22151. https:// doi.org/10.1371/journal.pone.0022151 PMID: 21799782

66. Gomes MF, Pastore Y Piontti A, Rossi L, Chao D, Longini I, Halloran ME, et al. Assessing the international spreading risk associated with the 2014 west african ebola outbreak. PLoS Curr. 2014;6:cd818f63d40e24aef769dda7df9eoda5. https://doi.org/10.1371/currents.outbreaks. cd818f63d40e24aef769dda7df9eoda5 PMID: 25642360

67. European Centre for Disease Prevention and Control (ECDC). Epidemiological update- Outbreak of Ebola virus disease in West Africa. Stockholm: ECDC; 2015 [Accessed: 30 Mar 2017]. Available from: http://ecdc. europa.eu/en/press/news/_layouts/forms/News_DispForm. aspx?List=8db7286c-fe2d-476c-9133-18ff4cb1b568\&ID=1151

68. OAG. Traffic Analyser FAQs. Luton: OAG. [Accessed: July 2015]. Available from: https://www.oag.com/traffic-analyser-faq

69. Stodden V, Donoho D, Fomel S, Friedlander M, Gerstein M, LeVeque $R$, et al. Reproducible research: addressing the need for data and code sharing in computational science. Comput Sci Eng. 2010;12(5):8-13. https://doi.org/10.1109/ MCSE.2010.113

70. Okeke IN, Edelman R. Dissemination of antibiotic-resistant bacteria across geographic borders. Clin Infect Dis. 2001;33(3):364-9. https://doi.org/10.1086/321877 PMID: 11438903

71. Lepelletier D, Andremont A, Grandbastien BNational Working Group. Risk of highly resistant bacteria importation from repatriates and travelers hospitalized in foreign countries: about the French recommendations to limit their spread. 
Travel Med. 2011;18(5):344-51. https://doi.org/10.1111/j.17088305.2011.00547.x PMID: 21896099

72. Chin CS, Sorenson J, Harris JB, Robins WP, Charles RC, Jean-Charles RR, et al. The origin of the Haitian cholera outbreak strain. N Engl J Med. 2011;364(1):33-42. https://doi. org/10.1056/NEJMoa1012928 PMID: 21142692

73. Cowling BJ, Park M, Fang VJ, Wu P, Leung GM, Wu JT. Preliminary epidemiological assessment of MERS-CoV outbreak in South Korea, May to June 2015. Euro Surveill. 2015;20(25):713. https://doi.org/10.2807/1560-7917.ES2015.20.25.21163 PMID: 26132767

74. Semenza JC, Sudre B, Miniota J, Rossi M, Hu W, Kossowsky $\mathrm{D}$, et al. International dispersal of dengue through air travel: importation risk for Europe. PLoS Negl Trop Dis. 2014;8(12):e3278. https://doi.org/10.1371/journal. pntd.0003278 PMID: 25474491

75. Khan K, Bogoch I, Brownstein JS, Miniota J, Nicolucci A, Hu W, et al. Assessing the origin of and potential for international spread of chikungunya virus from the Caribbean. PLoS Curr. 2014;6:2134aoa7bf37fd8d388181539fea2da5. https://doi. org/10.1371/currents.outbreaks.2134aoa7bf37fd8d388181539f ea2da5 PMID: 24944846

76. Rezza G, Nicoletti L, Angelini R, Romi R, Finarelli AC, Panning $M$, et al. Infection with chikungunya virus in Italy: an outbreak in a temperate region. Lancet. 2007;370(9602):1840-6. https://doi.org/10.1016/S0140-6736(07)61779-6 PMID: 18061059

77. Read JM, Diggle PJ, Chirombo J, Solomon T, Baylis M. Effectiveness of screening for Ebola at airports. Lancet. 2015;385(9962):23-4. https://doi.org/10.1016/S01406736(14)61894-8 PMID: 25467590

78. Apenteng 00, Ismail NA. Modeling the impact of international travellers on the trend of the HIV/AIDS epidemic. Proceedings of the World Congress on Engineering and Computer Science (WCECS) 2014 Vol II. WCECS 2014, 22-24 October 2014, San Francisco, US.

79. Apolloni A, Poletto C, Colizza V Age-specific contacts and travel patterns in the spatial spread of $2009 \mathrm{H}_{1} \mathrm{~N}_{1}$ influenza pandemic. BMC Infect Dis. 2013;13:176. https://doi. org/10.1186/1471-2334-13-176 PMID: 23587010

8o. Arino J, Khan K. Using mathematical modeling to integrate disease surveillance and global air transportation data. In: Chen D, Moulin B, Wu J, eds. Analyzing and modeling spatial and temporal dynamics of infectious diseases. Hoboken, New Jersey: John Wiley \& Sons, Inc.; 2015.

81. Bogoch II, Brady OJ, Kraemer MUG, German M, Creatore MI, Brent S, et al. Potential for Zika virus introduction and transmission in resource-limited countries in Africa and the Asia-Pacific region: a modelling study. Lancet Infect Dis. 2016;16(11):1237-45. https://doi.org/10.1016/S14733099(16)30270-5 PMID: 27593584

82. Bogoch II, Brady OJ, Kraemer MUG, German M, Creatore MI, Kulkarni MA, et al. Anticipating the international spread of Zika virus from Brazil. Lancet. 2016;387(10016):335-6. https://doi. org/10.1016/S0140-6736(16)00080-5 PMID: 26777915

83. Bowen J, Laroe C. Airline networks and the international diffusion of severe acute respiratory syndrome (SARS). Geogr J. 2006;172(2):130-44. https://doi. org/10.1111/j.1475-4959.2006.00196.x

84. Brannen DE, Alhammad A, Branum M, Schmitt A. International air travel to Ohio, USA, and the impact on malaria, influenza, and hepatitis A. Scientifica (Cairo). 2016;2016:8258946. https://doi.org/10.1155/2016/8258946 PMID: 27123365

85. Brockmann D, Hufnagel L, Geisel T. Dynamics of modern epidemics. In: SARS: A case study in emerging infections. 2007.

86. Brown EB, Adkin A, Fooks AR, Stephenson B, Medlock JM, Snary EL. Assessing the risks of West Nile virus-infected mosquitoes from transatlantic aircraft: implications for disease emergence in the United Kingdom. Vector Borne Zoonotic Dis. 2012;12(4):310-20. https://doi.org/10.1089/vbz.2010.0176 PMID: 22217181

87. Caley P, Becker NG, Philp DJ. The waiting time for inter-country spread of pandemic influenza. PLoS One. 2007;2(1):e143. https://doi.org/10.1371/journal.pone.0000143 PMID: 17206278

88. Cauchemez S, Ledrans M, Poletto C, Quenel P, de Valk H, Colizza V, et al. Local and regional spread of chikungunya fever in the Americas. Euro Surveill. 2014;19(28):20854. https://doi. org/10.2807/1560-7917.ES2014.19.28.20854 PMID: 25060573

89. Cheng Q, Jing Q, Spear RC, Marshall JM, Yang Z, Gong P. The interplay of climate, intervention and imported cases as determinants of the 2014 dengue outbreak in Guangzhou. PLoS Negl Trop Dis. 2017;11(6):e0005701. https://doi.org/10.1371/ journal.pntd.0005701 PMID: 28640895
90. Chong KC, Fong HF, Zee CY. Estimating the incidence reporting rates of new influenza pandemics at an early stage using travel data from the source country. Epidemio Infect. 2014;142(5):955-63. https://doi.org/10.1017/ So950268813002550 PMID: 24107289

91. Chong KC, Ying Zee BC. Modeling the impact of air, sea, and land travel restrictions supplemented by other interventions on the emergence of a new influenza pandemic virus. BMC Infect Dis. 2012;12(1):309. https://doi.org/10.1186/1471-2334-12-309 PMID: 23157818

92. Colizza V, Barrat A, Barthélemy M, Vespignani A. Predictability and epidemic pathways in global outbreaks of infectious diseases: the SARS case study. BMC Med. 2007;5:34. https:// doi.org/10.1186/1741-7015-5-34 PMID: 18031574

93. Cooper BS, Pitman RJ, Edmunds WJ, Gay NJ. Delaying the international spread of pandemic influenza. PLoS Med. 2006;3(6):e212. https://doi.org/10.1371/journal. pmed.0030212 PMID: 16640458

94. Dembele B, Yakubu AA. Controlling imported malaria cases in the United States of America. Math Biosci Eng. 2017;14(1):95109. https://doi.org/10.3934/mbe.2017007 PMID: 27879122

95. Dorigatti I, Hamlet A, Aguas R, Cattarino L, Cori A, Donnelly $\mathrm{CA}$, et al. International risk of yellow fever spread from the ongoing outbreak in Brazil, December 2016 to May 2017. Euro Surveill. 2017;22(28):30572. https://doi.org/10.2807/15607917.ES.2017.22.28.30572 PMID: 28749337

96. Epstein JM, Goedecke DM, Yu F, Morris RJ, Wagener DK, Bobashev GV. Controlling pandemic flu: the value of international air travel restrictions. PLoS One. 2007;2(5):e401. https://doi.org/10.1371/journal.pone.0000401 PMID: 17476323

97. Flahault A, Vergu E, Coudeville L, Grais RF. Strategies for containing a global influenza pandemic. Vaccine. 2006;24(4446):6751-5. https://doi.org/10.1016/j.vaccine.2006.05.079 PMID: 16843574

98. Gardner L, Chen N, Sarkar S. Vector status of Aedes species determines geographical risk of autochthonous Zika virus establishment. PLoS Negl Trop Dis. 2017;11(3):e0005487. https://doi.org/10.1371/journal.pntd.0005487 PMID: 28339472

99. Gardner LM, Chughtai AA, Maclntyre CR. Risk of global spread of Middle East respiratory syndrome coronavirus (MERS-CoV) via the air transport network. J Travel Med. 2016;23(6):tawo63. https://doi.org/10.1093/jtm/tawo63 PMID: 27601536

100. Gardner LM, Fajardo D, Waller ST, Wang O, Sarkar S. A predictive spatial model to quantify the risk of air-travelassociated dengue importation into the United States and europe. J Trop Med. 2012;2012:103679. PMID: 22523497

101. Gardner LM, Sarkar S. Risk of dengue spread from the Philippines through international air travel. Transp Res Rec. 2015;2501(1):25-30. https://doi.org/10.3141/2501-04

102. Gautreau A, Barrat A, Barthélemy M. Arrival time statistics in global disease spread. J Stat Mech Theory Exp. 2007;2007(e):Lo9001.

103. Goedecke DM, Bobashev GV, Yu F. A stochastic equationbased model of the value of international air-travel restrictions for controlling pandemic flu. Proceedings of the 2007 Winter Simulation Conference, Washington DC, 9-12 December 2007. IEEE. Available from; http://www.informs-sim.org/ wsco7papers/187.pdf

104. Goubar A, Bitar D, Cao WC, Feng D, Fang LQ, Desenclos JC. An approach to estimate the number of SARS cases imported by international air travel. Epidemiol Infect. 2009;137(7):1019-31. https://doi.org/10.1017/ S0950268808001635 PMID: 19079846

105. Grills A, Morrison S, Nelson B, Miniota J, Watts A, Cetron MS. Projected Zika virus importation and subsequent ongoing transmission after travel to the 2016 Olympic and Paralympic Games - country-specific assessment, July 2016. MMWR Morb Mortal Wkly Rep. 2016;65(28):711-5. https://doi.org/10.15585/ mmwr.mm6528e1 PMID: 27442184

106. Hanvoravongchai P, Coker R. Early reporting of pandemic flu and the challenge of global surveillance: a lesson for Southeast Asia. Southeast Asian J Trop Med Public Health. 2011;42(5):1093-9. PMID: 22299434

107. Hatz C, Werlein J, Mutsch M, Hufnagel M, Behrens RH. Japanese encephalitis: defining risk incidence for travelers to endemic countries and vaccine prescribing from the UK and Switzerland. J Travel Med. 2009;16(3):200-3. https://doi. org/10.1111/j.1708-8305.2009.00334.x PMID: 19538582

108. Hollingsworth TD, Ferguson NM, Anderson RM. Will travel restrictions control the international spread of pandemic influenza? Nat Med. 2006;12(5):497-9. https://doi. org/10.1038/nmo506-497 PMID: 16675989

109. Hollingsworth TD, Ferguson NM, Anderson RM. Frequent travelers and rate of spread of epidemics. Emerg Infect Dis. 
2007;13(9):1288-94. https://doi.org/10.3201/eid1309.070081 PMID: 18252097

110. $\mathrm{Hsu} \mathrm{Cl}$, Shih $\mathrm{HH}$. Transmission and control of an emerging influenza pandemic in a small-world airline network. Accid Anal Prev. 2010;42(1):93-100. https://doi.org/10.1016/j. aap.2009.07.004 PMID: 19887149

111. Hwang GM, Mahoney PJ, James JH, Lin GC, Berro AD, Keybl $M A$, et al. A model-based tool to predict the propagation of infectious disease via airports. Travel Med Infect Dis. 2012;10(1):32-42. https://doi.org/10.1016/j.tmaid.2011.12.003 PMID: 22245113

112. Johansson MA, Arana-Vizcarrondo N, Biggerstaff BJ, Gallagher N, Marano N, Staples JE. Assessing the risk of international spread of yellow fever virus: a mathematical analysis of an urban outbreak in Asuncion, 2008. Am J Trop Med Hyg. 2012;86(2):349-58. https://doi.org/10.4269/ ajtmh.2012.11-0432 PMID: 22302873

113. Johansson MA, Powers AM, Pesik N, Cohen NJ, Staples JE. Nowcasting the spread of chikungunya virus in the Americas. PLoS One. 2014;9(8):e104915. https://doi.org/10.1371/journal. pone.0104915 PMID: 25111394

114. Kenah E, Chao DL, Matrajt L, Halloran ME, Longini IM Jr. The global transmission and control of influenza. PLoS One. 2011;6(5):e19515. https://doi.org/10.1371/journal. pone.0019515 PMID: 21573121

115. Kernéis S, Grais RF, Boëlle PY, Flahault A, Vergu E. Does the effectiveness of control measures depend on the influenza pandemic profile? PLoS One. 2008;3(1):e1478. https://doi. org/10.1371/journal.pone.0001478 PMID: 18213386

116. Khan K, Arino J, Hu W, Raposo P, Sears J, Calderon F, et al. Spread of a novel influenza $A\left(\mathrm{H}_{1} \mathrm{~N}_{1}\right)$ virus via global airline transportation. N Engl J Med. 2009;361(2):212-4. https://doi. org/10.1056/NEJMco904559 PMID: 19564630

117. Khan K, Memish ZA, Chabbra A, Liauw J, Hu W, Janes DA, et al. Global public health implications of a mass gathering in Mecca, Saudi Arabia during the midst of an influenza pandemic. J Travel Med. 2010;17(2):75-81. https://doi. org/10.1111/j.1708-8305.2010.00397.x PMID: 20412172

118. Khan K, Sears J, Hu VW, Brownstein JS, Hay S, Kossowsky D, et al. Potential for the international spread of middle East respiratory syndrome in association with mass gatherings in saudi arabia. PLoS Curr. 2013;5:a7b70897ac2fa4f79b59f9od24c86ob8. https://doi.org/10.1371/currents.outbreaks. a7b70897ac2fa4f79b59f9od24c86ob8 PMID: 23884087

119. Knipl D, Röst G, Wu J. Epidemic spread and variation of peak times in connected regions due to travel-related infections: dynamics of an antigravity-type delay differential model. SIAM J Appl Dyn Syst. 2013;12(4):1722-62. https://doi. org/10.1137/130914127

120. Lawyer G. Measuring the potential of individual airports for pandemic spread over the world airline network. BMC Infect Dis. 2016;16:70. PMID: 26861206

121.Lourenço J, Recker M. The 2012 Madeira dengue outbreak: epidemiological determinants and future epidemic potential. PLoS Negl Trop Dis. 2014;8(8):e3083. https://doi.org/10.1371/ journal.pntd.0003083 PMID: 25144749

122. Marcelino J, Kaiser M. Critical paths in a metapopulation model of $\mathrm{H}_{1} \mathrm{~N}_{1}$ : Efficiently delaying influenza spreading through flight cancellation. PLoS Curr. 2012;4:fca8. https:// doi.org/10.1371/4f8c9a2e1fca8 PMID: 22919563

123. Massad E, Burattini MN, Khan K, Struchiner CJ, Coutinho FAB, Wilder-Smith A. On the origin and timing of Zika virus introduction in Brazil. Epidemiol Infect. 2017;145(11):2303-12. https://doi.org/10.1017/So950268817001200 PMID: 28675351

124. Massad E, Tan SH, Khan K, Wilder-Smith A. Estimated Zika virus importations to Europe by travellers from Brazil. Glob Health Action. 2016;9(1):31669. https://doi.org/10.3402/ gha.v9.31669 PMID: 27193266

125. Massad E, Wilder-Smith A. Risk estimates of dengue in travelers to dengue endemic areas using mathematical models. J Travel Med. 2009;16(3):191-3. https://doi.org/10.1111/j.17088305.2009.00310.x PMID: 19538580

126. Massad E, Wilder-Smith A, Ximenes R, Amaku M, Lopez LF, Coutinho FA, et al. Risk of symptomatic dengue for foreign visitors to the 2014 FIFA World Cup in Brazil. Mem Inst Oswaldo Cruz. 2014;109(3):394-7. https://doi.org/10.1590/00740276140133 PMID: 24863976

127. Matrajt L, Halloran ME, Longini IM Jr. Optimal vaccine allocation for the early mitigation of pandemic influenza. PLoS Comput Biol. 2013;9(3):e1002964. https://doi.org/10.1371/ journal.pcbi.1002964 PMID: 23555207

128. Meloni S, Perra N, Arenas A, Gómez S, Moreno Y, Vespignani A. Modeling human mobility responses to the large-scale spreading of infectious diseases. Sci Rep.
2011;1:62. https://doi.org/10.1038/srepooo62 PMID: 22355581

129. Merler S, Ajelli M. The role of population heterogeneity and human mobility in the spread of pandemic influenza. Proc Biol Sci. 2010;277(1681):557-65. https://doi.org/10.1098/ rspb.2009.1605 PMID: 19864279

130. Nah K, Mizumoto K, Miyamatsu Y, Yasuda Y, Kinoshita $\mathrm{R}$, Nishiura $\mathrm{H}$. Estimating risks of importation and local transmission of Zika virus infection. Peer). 2016;4:e1904. https://doi.org/10.7717/peerj.1904 PMID: 27069825

131. Nah K, Otsuki S, Chowell G, Nishiura H. Predicting the international spread of Middle East respiratory syndrome (MERS). BMC Infect Dis. 2016;16:356. https://doi.org/10.1186/ S12879-016-1675-Z PMID: 27449387

132. Napoli C, Salcuni P, Pompa MG, Declich S, Rizzo C. Estimated imported infections of Chikungunya and Dengue in Italy, 2008 to 2011. J Travel Med. 2012;19(5):294-7. https://doi. org/10.1111/j.1708-8305.2012.00640.x PMID: 22943269

133. Paul M, Held L, Toschke AM. Multivariate modelling of infectious disease surveillance data. Stat Med. 2008;27(29):6250-67. https://doi.org/10.1002/sim.3440 PMID: 18800337

134. Pinsent A, Read IM, Griffin IT, Smith V, Gething PW, Ghani AC, et al. Risk factors for UK Plasmodium falciparum cases. Malar J. 2014;13:298. https://doi.org/10.1186/14752875-13-298 PMID: 25091803

135. Poletto C, Boëlle PY, Colizza V. Risk of MERS importation and onward transmission: a systematic review and analysis of cases reported to WHO. BMC Infect Dis. 2016;16(1):448. https://doi.org/10.1186/s12879-016-1787-5 PMID: 27562369

136. Poletto C, Gomes MF, Pastore y Piontti A, Rossi L, Bioglio L, Chao DL, et al. Assessing the impact of travel restrictions on international spread of the 2014 West African Ebola epidemic. Euro Surveill. 2014;19(42):20936. https://doi. org/10.2807/1560-7917.ES2014.19.42.20936 PMID: 25358040

137. Poletto C, Tizzoni M, Colizza V. Heterogeneous length of stay of hosts' movements and spatial epidemic spread. Sci Rep. 2012;2:476. https://doi.org/10.1038/srepo0476 PMID: 22741060

138. Poletto C, Tizzoni M, Colizza V. Human mobility and time spent at destination: impact on spatial epidemic spreading. J Theor Biol. 2013;338:41-58. https://doi.org/10.1016/j. jtbi.2013.08.032 PMID: 24012488

139. Polwiang S. The estimation of imported dengue virus from Thailand. I Travel Med. 2015;22(3):194-9. https://doi. org/10.1111/jtm.12193 PMID: 25728849

140. Rocklöv J, Quam MB, Sudre B, German M, Kraemer MUG, Brady 0 , et al. Assessing seasonal risks for the introduction and mosquito-borne spread of Zika virus in Europe. EBioMedicine. 2016;9:250-6. https://doi.org/10.1016/j. ebiom.2016.06.009 PMID: 27344225

141. Ruan S, Wang W, Levin SA. The effect of global travel on the spread of sars. Math Biosci Eng. 2006;3(1):205-18. https:// doi.org/10.3934/mbe.2006.3.205 PMID: 20361819

142. Sato A, Ito I, Sawai H, Iwata K. An epidemic simulation with a delayed stochastic SIR model based on international socioeconomic-technological databases. Proceedings of the 2015 IEEE International Conference on Big Data. Santa Clara, US, 29 October-1 November 2015. BIG DATA '15. 2015. https:// doi.org/http://dx.doi.org/10.1109/BigData.2015.7364074

143. Schneider CM, Mihaljev T, Havlin S, Herrmann HJ. Suppressing epidemics with a limited amount of immunization units. Phys Rev E Stat Nonlin Soft Matter Phys. 2011;84(6 Pt 1):061911. https://doi.org/10.1103/PhysRevE.84.061911 PMID: 22304120

144. Struchiner CJ, Rocklöv J, Wilder-Smith A, Massad E. Increasing dengue incidence in Singapore over the past 40 years: population growth, climate and mobility. PLoS One. 2015;10(8):e0136286. https://doi.org/10.1371/journal. pone.0136286 PMID: 26322517

145. Tatem AJ, Hay SI, Rogers DJ. Global traffic and disease vector dispersal. Proc Natl Acad Sci U S A. 2006;103(16):62427. https://doi.org/10.1073/pnas.0508391103 PMID: 16606847

146. Tatem AJ, Rogers DJ, Hay SI. Estimating the malaria risk of African mosquito movement by air travel. Malar J. 2006;5:57. https://doi.org/10.1186/1475-2875-5-57 PMID: 16842613

147. Tian H, Sun Z, Faria NR, Yang J, Cazelles B, Huang S, et al. Increasing airline travel may facilitate co-circulation of multiple dengue virus serotypes in Asia. PLoS Negl Trop Dis. 2017;11(8):e0005694. https://doi.org/10.1371/journal. pntd.0005694 PMID: 28771468

148. Tuncer N, Le T. Effect of air travel on the spread of an avian influenza pandemic to the United States. Int J Crit Infrastruct Prot.2014;7(1):27-47. https://doi.org/10.1016/j. ijcip.2014.02.001 
149.

Urabe CT, Tanaka G, Aihara K, Mimura M. Parameter scaling for epidemic size in a spatial epidemic model with mobile individuals. PLoS One. 2016;11(12):e0168127. https:// doi.org/10.1371/journal.pone.0168127 PMID: 27973605

150. Wilder-Smith A, Leong WY. Importation of yellow fever into China: assessing travel patterns. J Travel Med. 2017;24(4). https://doi.org/10.1093/jtm/taxoo8 PMID: 28426111

151. Wilder-Smith A, Leong WY, Lopez LF, Amaku M, Quam M, Khan $\mathrm{K}$, et al. Potential for international spread of wild poliovirus via travelers. BMC Med. 2015;13:133. https://doi.org/10.1186/ S12916-015-0363-y PMID: 26044336

152. Wilder-Smith A, Quam M, Sessions O, Rocklov J, Liu-Helmersson J, Franco L, et al. The 2012 dengue outbreak in Madeira: exploring the origins. Euro Surveill.

2014;19(8):20718. https://doi.org/10.2807/1560-7917. ES2014.19.8.20718 PMID: 24602277

153. Wilson SE, Khan K, Gilca V, Miniota J, Deeks SL, Lim G, et al. Global travel patterns and risk of measles in Ontario and Quebec, Canada: 2007-2011. BMC Infect Dis. 2015;15:341. https://doi.org/10.1186/s12879-015-1039-0 PMID: 26282392

154. Xiao L, Zhang H, Tang Y, Ren LY. Risk analysis of

international spreading in Ebola outbreak to China compared to social media. 12th Proceedings of the International Conference on Information Systems for Crisis Response and Management (ISCRAM). Krystiansand, Norway, 24-27 May 2015.

155. Yoneyama T, Krishnamoorthy M. Simulating the spread of influenza pandemic of considering international traffic. Simulation. 2012;88(4):437-49. https://doi. org/10.1177/0037549711405077

\section{License, supplementary material and copyright}

This is an open-access article distributed under the terms of the Creative Commons Attribution (CC BY 4.0) Licence. You may share and adapt the material, but must give appropriate credit to the source, provide a link to the licence and indicate if changes were made.

Any supplementary material referenced in the article can be found in the online version.

This article is copyright of the authors or their affiliated institutions, 2019. 